\title{
Understanding the commercial mortgage-backed securities market in the hospitality sector
}

Received: 8 March 2004

\section{Phillip Gordon}

joined Perkins Coie in 2003. His practice focuses primarily on private equity transactions and real estate, with an emphasis on hotel transactions, as well as general mergers and acquisitions. He has earned international recognition for his work in the acquisition, disposition, financing and negotiation of management agreements for major hotel owners in the USA and Europe. His clients include private equity firms, hotel investment groups, hotel property owners and design and development companies. Phil received his law degree from Chicago Law School and undergraduate degrees from Oxford University and The University of Witwatersrand in South Africa. Prior to joining Perkins Coie, Phil was a partner at Altheimer \& Gray, Chicago.

\section{Daniel Marre}

is a partner in the Chicago office of Perkins Coie LLP. He is a member of the firm's real estate group and has extensive experience in the commercial property industry, including hotel, office and retail acquisitions, dispositions, construction, development and leasing. He has spent a significant portion of his career working on major hotel projects internationally, particularly in Central and Eastern Europe and the Caribbean. Daniel received his law degree from Northwestern University School of Law and his undergraduate degree from the University of Chicago. Prior to joining Perkins Coie in 2003, Daniel was a partner at Altheimer \& Gray, Chicago.

\section{Bruce Bonjour}

joined Perkins Coie in 2003 from Altheimer \& Gray where he was Chair of the Finance Practice Group. Bruce's practice focuses on real estate and other securitisations, structured finance, new market tax credits and public finance. His clients include private equity firms, REITs and public entities. He is a member of the National Association of Bond Attorneys. Bruce received his JD from George Washington University, his MA from the State University of New York and his BA from Albion College.
Abstract
Before the advent of the commercial mortgage-backed securities (CMBS) market, long-term permanent real estate lending had been traditionally limited to commercial banks, thrifts and insurance companies that provided new mortgage loan originations to local markets. The CMBS market was born from the lending crunch that developed in the 1980s, as some traditional lenders backed away from real estate lending.
Financial intermediaries filled this gap in the market by constructing new forms of real estate debt securities which appealed to a greater range of investors. As a result, since the inception of the CMBS market there has been a broader range of investors in real estate securities, including money managers,

Daniel G. M. Marre Perkins Coie 131 South Dearborn Street, Suite 1700 Chicago, IL 60603-5559, USA

Tel: +1 3123248632

Fax: +1 3123249632

E-mail: dmarre@perkinscoie.com 
hedge funds, pension funds, real estate funds and mutual funds.

The objective of this paper is to provide a general overview of the CMBS securitisation process as it relates to hotels and discuss the advantages and disadvantages of the CMBS market, challenges confronting the CMBS hospitality sector and the servicing of CMBS.

\section{Keywords:}

commercial mortgage-backed securities (CMBS), hospitality, financing, hotels, hotel management

\section{THE SIZE OF THE CMBS MARKET}

The CMBS market has grown to over $\$ 550$ bn in CMBS backed by US real estate mortgage loans. ${ }^{1}$ For the year 2004, the total new issue volume of CMBS amounted to approximately $\$ 92.9 \mathrm{bn}$ backed by US real estate mortgage debt and $\$ 34.3$ bn backed by international real estate mortgage debt. ${ }^{2}$ It is estimated that the annual secondary market trading (non-new issue) of CMBS is well over \$400bn. ${ }^{3}$ Clearly, the CMBS market has become an increasingly advantageous vehicle for many issuers and investors.

\section{THE NATURE OF CMBS}

A CMBS is the product of a process of pooling real estate loans into an entity which is a flow-through for federal income tax purposes, which then issues debt securities backed by the interest and principal of the underlying loans. The first step in this process is for a financial institution to originate the individual commercial loans. The commercial loan is originated either to finance a commercial purchase or to refinance a prior mortgage obligation. The second step is to package the individual loans and transfer them into an entity which then issues notes. The notes are broken down into different risk levels and either rated by rating agencies or remain unrated. Finally, the notes are sold to investors in either the public or the private markets.

There are generally two types of CMBS: a government agency CMBS and a private-label CMBS. The US government's housing agencies, Government National Mortgage Association (GNMA), Federal National Mortgage Association (FNMA) and Federal Home Loan Mortgage Corporation (FHLMC), each issue forms of CMBS. Because the mission of these agencies is to provide funding for residential housing, the CMBS they issue are generally secured by multi-family housing loans, although GNMA also issues securities backed by loans on nursing-home projects and healthcare facilities. But the majority of CMBS issued today are non-agency or 'privatelabel' securities. Most private-label CMBS are backed by newly originated loans, rather than seasoned commercial loans. These types of private-label CMBS generally fall into two categories: those 


\section{Diversity of borrowers}

\section{Basic securitisation}

\section{Residual interest}

\section{Special purpose entities}

backed by loans made to a single borrower and those backed by loans made to multiple borrowers. A CMBS representing loans to a single borrower or a group of affiliated borrowers is typically backed by large commercial properties, such as hotels, office buildings or shopping centres; however, these securities obviously lack diversity with respect to borrower creditworthiness and property type. Furthermore, these securities represent a small portion of the CMBS market. ${ }^{4}$ On the other hand, a CMBS representing loans made to multiple borrowers provides more diversity by providing different borrowers and different property types. In addition, because these loans are typically underwritten with the intent of securitisation, the loans tend to be more homogeneous and have uniform underwriting standards. These securities represent an overwhelming majority of the CMBS market.

\section{THE SECURITISATION PROCESS}

The securitisation process is essentially the process of transforming an illiquid asset into a security. In its simplest form, a securitisation involves the origination of loans by an originator through one or more borrowers; the sale of a pool of such loans to a specialpurpose entity (SPE) that meets certain legal and accounting requirements; and the issuance and sale by the SPE, in either a private placement or public offering, of debt securities that are subsequently satisfied from the proceeds of, and secured by, the loans. Upon the closing of a securitisation, the purchase price paid by the investors for the securities (usually banks, insurance companies and pension funds) flows to the issuer of securities (ie the SPE) and from the issuer to the originator. The originator will generally source the loans and bundle them so that the purchase of the loans by the SPE and the sale of the securities occur virtually simultaneously.

In addition to issuing debt securities that are subsequently satisfied from the proceeds of, and secured by, the loans, the issuer typically also creates a residual interest in the issuer that entitles the originator to funds remaining after all obligations to the holders of the debt securities have been satisfied. During the term of the securitisation, payments on the loans are collected by a servicing entity, deposited and invested under the control of a trustee and disbursed by the trustee to the security holders in payment of the debt securities.

In many cases, a 'two-step' structure is implemented to satisfy certain legal and accounting requirements for the purposes of ensuring that the originator can remove the loans from the originator's balance sheet and book a profit or loss for accounting purposes, and that the loans are protected from the claims of creditors of the originator, especially in the event of bankruptcy of the originator. The two-step structure involves the originator transferring the loans to an intermediate SPE that is a whollyowned subsidiary of the originator, but which is only permitted to 


\section{Conduits}

engage in the business of acquiring, owning and selling the loans, has at least one independent director and is restricted in various ways from entering into voluntary bankruptcy and other prohibited acts; and the intermediate SPE selling the loans to the issuer of debt securities.

The above description of the securitisation process is very basic. Each type of asset presents unique structuring considerations, however. The securitisation process is generally more costly than traditional forms of financing, which means that the value of a pool of loans must be significant to justify the costs of securitisation. ${ }^{5}$ To overcome this hurdle, securitisations at the low end are structured by 'conduit' issuers maintained by banks and investment bankers. In these securitisations, originators sell their loans to a conduit issuer that aggregates the loans from multiple originators to create large pools to support the securities issued by the conduit issuer. Although the conduit issuers take a bigger share of the 'pie', originators continue to seek out the securitisation process for the numerous benefits it provides to their business, including the following:

- the originator is immediately able to recognise a gain or loss on the sale of the loans, and the loans are moved off its balance sheet

- the originator can act as the servicer of the loans so the securitisation is transparent to the originator's customers; in addition, the originator receives a fee for its services.

\section{ADVANTAGES AND DISADVANTAGES OF THE CMBS MARKET}

In addition to the advantages and disadvantages of the securitisation process discussed above with respect to originators, there are other pros and cons of the CMBS market. The advantages of entering the CMBS market include the following.

\section{Advantages}

- Higher proceeds for issuers and investors. The very nature of pooling loans has reduced the volatility of the CMBS lending market. Thus, investors can match their investment dollars more accurately with the risk they are willing to take. Additionally, lending skills brought to CMBS transactions by underwriters and rating agencies, among others, has helped discipline the lending process. Less overall volatility and the ability to match more closely an appetite for risk have brought more dollars into the market and have permitted lenders to loan more money to borrowers than conventional loans would allow.

- Lower overall borrowing cost. While front-end transaction costs are higher than for conventional financings, the overall cost to the borrower is generally lower.

- Non-recourse. The very nature of the SPEs that serve as borrowers in CMBS transactions means that loans are nonrecourse to the 'sponsors' (except for the usual carve-outs for fraud, waste, misapplication of funds, etc). 
Disadvantages
- No financial covenants. A low debt-service reserve is usually the substitute.

On the other hand, the disadvantages of entering the CMBS market include the following.

- Inflexible terms. The 'first-loss' buyers (those buying below investment grade who will be the first to suffer should there be an interruption of loan payment proceeds) have developed, and the market has responded with requiring certain standard provisions that are not negotiable.

- 'No one is home.' The holders of the debt are not part of the issuance process. Borrowers in default, or in imminent default, must deal with a master servicer or a special servicer. The servicer's rights to agree to changes in the documentation are quite circumscribed. While borrowers can generally negotiate changes in the deal with conventional lenders who still own a large part of and service conventional loans, there is far less latitude in dealing with CMBS issues, where the holdings are, by design, scattered among a multitude of holders of different classes.

- No subordinate debt financing is permitted. It is an invariable term of CMBS financing that no debt secured by the property other than the securitised mortgage is permitted, and if any subordinate debt is permitted at all, it is contemplated in the initial financing and is secured only by the interests in the borrowing entity. Consequently, if there is either the opportunity or the need to raise additional capital, that capital needs to come in as equity, and even then the terms of such equity tend to be circumscribed by the loan documentation. These restrictions therefore make it difficult and expensive to raise subordinated capital, even if that capital is equity. Not surprisingly, therefore, given the inflexibility of the CMBS terms, the difficulty in raising subordinate finance and other terms which restrict flexibility, the most common way for borrowers out of the box is to refinance the debt as a whole. If there are yield maintenance or other restrictions on prepayment, this can be a very expensive process.

- Release provisions are possible, but may not be practical. In multi-property securitisations on behalf of a single borrower, there will often be release provisions for sales of individual properties, but these release provisions may not be practical. Release provisions will generally provide for paydowns in excess of the allocated part of the loan to the property being sold, which may require the borrower to reach into their pocket to obtain a release.

- Rating agency approval is required for most actions outside the ordinary course. The rating agencies are essentially the gatekeepers for the bond holders following the issuance of the securities. Their consent is therefore required for anything 
Growth of CMBS

\section{Challenges in the hospitality industry}

which may affect the quality of the debt or the structure of the deal, including the identity of an acquirer (which invariably will be limited by the loan documentation to an institutional investor).

\section{PARTICULAR CHALLENGES IN THE HOSPITALITY SECTOR}

In February 2003, Deutsche Bank Securities completed a \$1.17bn facility secured by mortgages on a portfolio of 15 hotels owned by a single private firm with hotels located in New York, San Francisco, Southern California, New Orleans and other major markets. The facility included a securitisation led and managed by Deutsche Bank Securities consisting of $\$ 700 \mathrm{~m}$ in mortgage notes with ten rated tranches, four classes of interest-only securities, $\$ 200 \mathrm{~m}$ in non-rated subordinated mortgage notes and a privately placed mezzanine loan.

The mere size of the foregoing transaction suggests that the CMBS market for the hospitality sector is robust and dynamic. Indeed, for the calendar year 2004, hotel CMBS offerings accounted for $\$ 8.85 \mathrm{bn}$ of CMBS offerings out of the total $\$ 127.2 \mathrm{bn}$ of CMBS offerings for the year, up a healthy 48.9 per cent from the previous year. ${ }^{6}$ But the CMBS market for the hospitality sector is vulnerable. For example, in May 2003 Wachovia Securities, Inc. reported: '[T]he hospitality sector, with its unique vulnerabilities to recent volatile travel patterns, is experiencing dramatic increases in loan delinquencies ...? 7

In addition to these market vulnerabilities, there are certain factors unique to the hospitality sector that make entering the CMBS market challenging. Hotel assets are usually managed onsite by a hotel management company which has a long-term contract giving it exclusive control over the operations of the hotel. Hotel managers generally have exclusive operational control over the property, which is managed, in the case of branded hotels, in accordance with the hotel manager's brand standards. Because the management agreements are long term, the ability of the owner or the lender to change management will be limited to circumstances outlined in the management agreement (such as failure by the manager of performance tests). In addition, hotels have relatively high fixed operating costs, which means that relatively small decreases in revenue can cause significant declines in net cash flow. Furthermore, the hotel and leisure industry experiences seasonal swings. Fluctuations are common with respect to revenues, occupancy levels, room rates and operating expenses. Finally, income from hotel operations is sensitive to external forces, such as economic conditions, terrorism, etc.

With respect to the management of hotel assets, the unique relationship between a hotel owner and a hotel manager is embodied in a hotel management agreement that frequently makes debt securitisation challenging. Hotel management agreements may take the form of a long-term management contract or an operating 
The hotel management agreement lease. The relevant terms of a hotel management agreement are as follows.

- The management agreement is frequently long term (20 years or more).

- The hotel manager is granted control of all cash receipts from operations and has day-to-day management responsibilities for the hotel, including authority to establish prices, rates and charges.

- The hotel manager employs all personnel subject to limited controls by the owner (eg approval of union contracts).

- The hotel manager is required to manage the hotel consistent with a specified standard or brand; to keep it in good repair; and to provide annual proposed operating and capital budgets for the hotel owner's approval.

- The operating income funds operating expenses, including the hotel manager's base and any incentive fees, and any required reserves, such as a furniture, fixture and equipment reserve. The hotel owner is obligated to advance working capital if operating income is insufficient.

- The hotel manager is usually protected by provisions that require rebuilding upon casualty and limit certain transfers of the hotel.

- The hotel management agreement may be terminated only under limited circumstances (typically, failure to achieve specified operating benchmarks or performance tests over a specified period - usually two years), and termination is often not permitted upon foreclosure of the hotel owner's mortgage or the sale of the hotel.

- The parent or sponsors of the hotel ownership entity often guarantee the management contract, raising non-consolidation issues in a CMBS offering.

Although a hotel management agreement provides assurance to a hotel owner that its asset will be managed properly, such agreements are generally not written with a view towards securitisation or do not adequately address certain issues from an investor perspective. The following issues generally will need to be addressed in connection with a CMBS offering secured by hotel assets.

\section{Budgets}

Unlike a budget for retail or office buildings' rental, which is reasonably predictable and objectively determinable for basic expenses such as taxes, insurance, maintenance and utilities, the budget for a full-service hotel is subject to great variance, vesting considerable discretion in the hotel manager to adjust hotel services constantly to meet the demands of guests and still conform to the standards established by the owner and the hotel chain. The hotel
Budgeting challenges 


\section{Alternate lockbox arrangements}

manager has wide latitude to adjust room rates, staffing levels, marketing activities and related services that will vary from day to day, week to week and season to season in response to business trends, conventions, tourism patterns and the like.

Investors and rating agencies have grown comfortable with the fact that hotel budgets cannot be controlled by CMBS documentation. Instead, CMBS documentation typically establishes parameters (eg minimum furniture, fixtures and equipment [FF\&E] reserves, procedures governing major improvements or alterations) to control certain features. Otherwise, rating agencies and investors appear to rely on natural owner/manager competing interests to yield favourable results in the budget process. CMBS documents will, however, require that the hotel owners may not exercise certain rights to approve or amend budgets without consent by the servicer if certain key business indicators (typically debt service coverage ratios) are not maintained.

\section{Reserves}

Because the hotel manager initially controls cash receipts from hotel operations, customary reserves for taxes, insurance, ground lease rent and other expenses cannot be effectively established with a CMBS servicer. To make hotel CMBS offerings consistent with other real estate mortgage securitisations, rating agencies and investors have become comfortable with the establishment of primary reserve accounts or procedures at the manager level, and if the primary reserve is not fully funded, a secondary reserve funded out of a lockbox arrangement that intercepts distributions from the hotel manager to the owner.

A typical CMBS lockbox structure provides that the cash receipts from the property must first be applied to a pre-established set of priorities such as real property taxes, ground lease rentals, insurance, utilities and payment of principal and interest on the debt, as well as to establish certain reserves for capital repair and improvement, tenant improvements, etc, before the remaining cash is made available to the owner. But in the case of full-service hotels operated by independent managers, this customary lockbox arrangement cannot be achieved since a typical hotel management agreement grants the hotel manager the primary right to receive and apply cash receipts from operations to pay operating expenses (including real estate taxes and insurance) and management fees, and to fund certain reserves, such as a specified percentage of cash flow dedicated to FF\&E. Investors and rating agencies have responded to this issue by creating two tiers of lockboxes or 'accounts'. The first tier is an account controlled by the hotel manager to pay operating expenses and fund important reserves (taxes, insurance and FF\&E). The second tier is a lockbox with the CMBS servicer to service the debt and to provide for any reserves or expenses not addressed in the hotel management agreement. Thus the CMBS servicer lockbox merely intercepts cash 


\section{Participation of the hotel manager}

\section{Working with working capital}

distributions from the hotel managers to the hotel owner. In order to maintain this two-tier structure, a hotel owner needs to obtain a series of acknowledgments or agreements from the hotel manager. This is usually accomplished in direction letters, consents or subordination and non-disturbance agreements that provide for some, but not all, of the following.

- Subordination of the management agreement in exchange for customary non-disturbance provisions.

- Estoppel representations as to the management agreement, the absence of defaults, the identification of hotel bank accounts and similar items.

- Consent to the collateral assignment of the management agreement to secure the CMBS transaction.

- Confirmation that the operating and reserve accounts established pursuant to the management agreement are the property of the hotel owner, held by the manager for the owner's benefit and will be segregated from all other funds held by the manager and not commingled.

- Provision for setting aside or otherwise reserving funds for taxes or insurance premiums at the manager or hotel level, thereby creating a practical substitute for provisions typically addressed in lockbox agreements with a CMBS servicer.

- Confirmation that all distributions to the hotel owner during the term of the CMBS transaction will instead be paid to the CMBS servicer lockbox.

- Filing of precautionary UCC (Uniform Commercial Code) financing statements.

- Receipt and disposition of insurance or condemnation proceeds.

\section{Cash traps}

A cash trap is a common feature in many CMBS offerings. The term 'cash trap' refers to the segregation of certain surplus cash flows, preventing the release of cash to the owner upon the failure of the property to meet a minimum debt service coverage ratio. As a result of a cash trap, surplus cash receipts not otherwise required to pay expenses or service debt (or to fund specified reserves) will not be released to the owner and, in some cases, will be applied to prepay the debt. A cash trap may present problems if, at the very moment an owner is no longer receiving cash flow, the owner finds that business conditions may trigger a provision in the management agreement requiring the owner to fund working capital. For these reasons, recent CMBS offerings have implemented the cash trap at different levels eg 50 per cent cash trap if net operating income (NOI) drops 10 per cent, 75 per cent cash trap if NOI drops 15 per cent, etc.

\section{Management agreements}

If negotiated by a knowledgable owner in a highly competitive environment for a valuable hotel asset, a hotel management 


\section{Alignment of interests}

Substitution of owner

\section{Exceptions to covenants}

agreement can provide an owner with favourable rights and opportunities. If a hotel is already subject to such a favourable hotel management agreement, the interests of the CMBS investors and the hotel's owner may be in general alignment. If an opportunity arises to negotiate or renegotiate such a hotel management agreement during the relatively short term of the CMBS transaction, either by amending an existing agreement or by replacing one chain with another chain, the interests of the CMBS investors and the hotel's owner should also be in alignment. But allowing an owner latitude to negotiate such changes is frequently a major issue in a hotel CMBS financing. Rating agencies are reluctant to give the owner free rein to amend management agreements or replace hotel flags or managers, but generally will agree to a list of approved managers. Likewise, sophisticated owners of hotels are equally reluctant to allow third parties with little general understanding of the hotel business (and the specific underlying asset) to have discretion to approve amendments to existing agreements or replace hotel chains and/or managers. This stalemate is typically resolved by providing that any material change to a management agreement requires a no-downgrade letter from the rating agencies. It is often possible to include a list of preapproved chains for each hotel incorporated directly into the CMBS loan documentation. It is also possible to obtain some flexibility for non-material amendments and to have certain proposed amendments to existing management agreements preapproved, thereby avoiding stalemates.

\section{Termination of the manager}

It is difficult to terminate most hotel management agreements upon a mortgage foreclosure, and the investment community has accepted this fact. Instead, the CMBS documentation typically provides that the CMBS servicer and various types of specified institutional investors will, upon foreclosure, have the right to step into the shoes of the owner upon material default or foreclosure.

\section{Negative covenants}

Customary CMBS negative covenants may require some modifications for hotel properties. For instance, it is commonly accepted that an SPE that owns real estate subject to CMBS debt should not incur additional debt (subject to minor exceptions for obligations to pay trade creditors or a pre-existing or unavoidable lease or similar obligation). But an owner of a hotel is often obligated under the hotel management agreement to fund working capital or repay key money. Since hotel managers are unwilling to release owners from such obligations, it is necessary to negotiate various protections for investors within CMBS loan agreements, including the establishment of a second-tier reserve to be funded by cash flows from other hotels or, in limited circumstances, the 


\section{Built-in approvals}

\section{Relationship with the hotel manager}

\section{Master vs special servicers}

\section{Prepayment issues}

funding of a reproduction limited reserve upfront for such purposes.

\section{Transfer restrictions}

Rating agencies and investors generally insist on limiting transfers of assets or equity ownership in CMBS offerings, and the restrictions are not always compatible with corresponding restrictions in hotel management agreements. To provide owners with flexibility, it is necessary to negotiate pre-approved parameters and identify pre-approved transferees in the CMBS documentation, as well as obtain the right to make other transfers upon receipt of a no-downgrade letter from the rating agencies and receipt of various legal opinions. Likewise, CMBS investors are often protected by obtaining consent from the hotel manager in the event of a transfer upon the foreclosure and subsequent sale of the hotel.

\section{SERVICING OF CMBS}

Servicers, special servicers, master servicers, operating advisers and others are involved in the administration of loan documents and mortgages securing CMBS debt. In a CMBS offering secured by owner-managed or owner-operated retail or office property, these servicers take on important roles, particularly when a mortgage is to be foreclosed or a receiver is to be appointed and it becomes important for the servicer to take control of the asset away from the owner. In the case of a full-service hotel already managed by an independent hotel manager who is experienced in the hotel business, the role of the CMBS servicer is much less important. In fact, it is unlikely that the CMBS servicer will need to assume control of the hotel, particularly since the hotel management agreement typically survives a mortgage foreclosure. Because CMBS servicers often enter a CMBS transaction at a late stage and are unfamiliar with the hotel business, their standard fee expectations are not reflective of their reduced roles in hotel CMBS transactions.

The CMBS structure generally calls for both a master and a special servicer. Sometimes the master and a special servicer are the same company; however, usually they are different. The master servicer generally deals with the loan before it goes into default. The loan is usually transferred to a special servicer soon after default or if there is an imminent default. Unfortunately, borrowers who attempt quickly to negotiate a prepayment, assumption or defeasance are quite often frustrated by dealing with several different personnel and companies when a loan is transferred from a master to a special servicer.

Borrowers who desire to prepay a loan in the CMBS market that is not permitted by the loan documentation will face serious resistance. This resistance is predicated upon the fact that investors are purchasing a stream of income. Hence, most CMBS loans will either have a lock-out, yield maintenance prepayment or 


\section{Enforcement of financial covenants}

\section{Limited flexibility in assisting borrowers in trouble}

defeasance. Under current market conditions, where interest rates have dropped precipitously from the time when the loans were originated, a yield maintenance prepayment fee can be staggering. Another option for repayment is defeasance, where the loan is assumed by a third-party shell corporation and government securities are purchased by the borrower. The government securities are then used to make all the loan payments, including the balloon payment at maturity. But defeasance also involves paying a yield maintenance fee as well as significant costs.

Borrowers will also encounter stricter enforcement of financial covenants. Because a CMBS servicer must prepare numerous reports for investors regarding the borrower's financial status, a CMBS servicer will not be as forgiving as a financial institution for incomplete or missing financial reports called for under the loan documents.

Borrowers who are at risk of imminent default will not receive much assistance from their servicers or otherwise. As discussed in the section on the securitisation process above, most CMBS offerings involve a securitisation process that provides certain tax advantages. In order to retain the tax-advantaged status, servicers are limited in what they can do in a workout situation. For example, a borrower cannot substitute the real property security for the loans from the principal business. Because the CMBS market considers the tax-advantaged status of the CMBS to be a material issue, servicers must often obtain opinions from specialist tax counsel before consummating certain workout arrangements. In addition, borrowers cannot rely on bankruptcy as a saviour. One of the key features and advantages of CMBS loans is their limited recourse nature. CMBS borrowers are generally organised as SPEs, which by their nature are judgment-proof. The loans are generally guaranteed by a creditworthy principal of the borrower, but the guarantee is usually limited to the non-recourse carveouts. The guarantees usually also have certain events that will trigger full recourse. One of those events is usually the bankruptcy of the borrower. Other springing events are often the transfer or encumbrance of the property without the lender's consent.

\section{References}

1. Real Estate Roundtable and Commercial Mortgage Securities Association (2003) Letter to the Board of Governors of the Federal Reserve System, the Office of the Comptroller of the Currency, the Federal Deposit Insurance Corporation and the Office of Thrift Supervision regarding 'Risked[sic]-Based Capital Guidelines; Implementation of New Basel Accord', 3 November, www.cmbs.org/regulatory/BASEL_II/11-032003_LETTER_TO_FED.pdf.

2. Commercial Mortgage Alert (2005) 10 March, available at www.cmalert.com.

3. Real Estate Roundtable and Commercial Mortgage Securities Association, ref. 1 above.

4. DeMichele, J. F. and Adams, W. J. (1998) 'Commercial Mortgage Backed Securities', in Fabozzi, F. J. and Jacob, D. P. (1998) The Handbook of Commercial Mortgage Backed Securities, 2nd edn, McGraw-Hill Education. 
5. Leixner, T. C. (1999) 'Securitization of Financial Assets', 1st September, available at http://pages.stern.nyu.edu/ igiddy/ABS/securitizationintro.htm.

6. Commercial Mortgage Alert, ref. 2 above.

7. Wachovia Securities, Inc. (2003) CMBS Performance in a Rising Interest Rate Environment, CMBS and Real Estate Research, 5 May. 